\title{
Analysis of computed discount rates for the largest companies of the mineral resources sector of Russia
}

\author{
Vladimir Nikolaevich Podkorytov *, and Lyudmila Anatolyevna Mochalova \\ Ural state mining University, Department of Economics and management, 620144, 30, Kuibyshev St., \\ Ekaterinburg, Russia
}

\begin{abstract}
The article provides a comparative analysis of discount rates for the largest companies in the mineral resources sector of Russia, which are calculated on the basis of statistical data from the US and Russian securities markets. Using the CAPM model (Capital Asset Pricing Model) for each selected company, various ruble discount rates were obtained. Calculations based on statistical data from the Russian securities market showed higher rates, and this, according to the authors, can negatively affect the assessment of potential investment projects in terms of their effectiveness. According to the results of the study, it was concluded that when calculating discount rates, it is advisable to use statistical data from the US securities market, since they give more objective results. The appropriateness of their use in forecasting the return on investment is largely due to the length of the retrospective period when calculating the premium for the risk of investing in stocks (from 1928 to the present), smoothing out market volatility at certain crisis times. The Russian securities market has a short retrospective, uneven dynamics of indicators, which does not allow full use of its statistical information. The authors see the prospect of further research in constructing special stochastic models for discount rates forecasting to evaluate investments in companies of the mineral resources sector of Russia.
\end{abstract}

\section{Introduction}

The discovery of new mineral deposits, as well as the current situation on the world market, indicate that the mineral and mineral resources sector of Russia will play a special role in the Russian economy for a long time. At the same time, both an increase in the extraction of raw materials and its maintenance at the current level are inextricably linked with the process of investing in companies of this complex. In its turn, the investment process requires, as a rule, significant investment, and, in this regard, the importance of evaluating the effectiveness of investment projects proposed for implementation increases. One of the most important indicators affecting performance criteria is the discount rate. Even its slight change can significantly affect the evaluation of the project and, accordingly, the possibility of its implementation.

\footnotetext{
* Corresponding author: Podkorytov.V@m.ursmu.ru
} 
The article presents the results of the analysis of the estimated values of discount rates by the authors in relation to the largest companies of the mineral resources sector of Russia, whose shares are among the blue chips of the Moscow Exchange stock sector (MOEX) and thus determine the financial stability of the country's economy.

\section{Materials and methods}

Theoretical and practical issues related to discount rate determination for commodity companies were previously raised by the authors of the article. In particular, in study [1] it was found that from the point of view of theory, the discount rate is, firstly, the minimum rate of profit that the investor is counting on, and secondly, alternative profitability, that is, an alternative to the project or business being evaluated as a whole. From the standpoint of practice, the CAPM (Capital Asset Pricing Model) proposed by U. Sharp was named as the most correct formula for calculating the indicator under review:

$$
i=R_{f}+\beta\left(R_{m}-R_{f}\right)
$$

where $R_{f}$ is the risk-free rate of return, $\%$;

$\beta$ - "beta" coefficient, acting as a measure of market risk, reflecting the sensitivity of changes in the value of assets depending on market profitability;

$\left(R_{m}-R_{f}\right)$ - premium for the risk of investing in shares equal to the difference between the rates of market profitability and the risk-free rate, $\%$.

It should be noted that at present various scientists are actively involved in calculating the discount rate. So, for example, S.G. Galevsky in work [2] proposes to calculate the indicator in question separately for cash inflows and outflows using the example of Rosneft PJSC, that is, to use two different interest rates that differ by a $\beta$ coefficient. P.E. Zhukov in article [3] proposes three models for analyzing changes in company value using stochastic discount rates to measure cost factors and empirically evaluate the weighted average cost of capital as an alternative to the traditional WACC calculation. Stochastic rates in the analysis of price indicators in stock markets are also considered in the works of foreign authors [4-6]. In their article Kuchko A.Yu. and Naumova O.A. [7] presents the results of the analysis of modern methods of assessing the discount rate in terms of sensitivity of the current value of cash flows to its change. Kovalenko A. V., Nikiforova V. D., Nikiforov A. A. in their work [8] propose to calculate the discount rate based on CAPM, which is a model using the fractal hypothesis in risks assessment.

With all the diversity of opinions, the simplest and transparent in practical application, as well as the corresponding concept of the discount rate, according to the authors of this article, is the classic model of CARM by U. Sharp. However, unfortunately, in all the abovementioned works, even with the separation of the CAPM model, it is not reflected that for calculation of the objective discount rate, not only the choice and use of a particular model is decisive. In practice of assessment of investments and business, the question often arises about the correctness and reliability of a particular information base when calculating discount rates according to the model by U. Sharp. In the study conducted by the authors, this base was, on the one hand, statistical data on the yield of the US stock market, as well as the yield on 10-year US government bonds, and on the other hand, similar information on the stock market and the government bond market of Russia.

\section{Results and discussion}

As a result of studies on determination of the types of soils based on morphological analysis of sections and the appearance of soils and data from past studies, it was established that the 
studied soils of the Tarnier deposit are brown podzolized (figure) [7, 8]. Other varieties of soil are absent. Table 1 presents the results of calculation of the discount rates at the beginning of 2020, based on information from the stock market and the US government bond market. As a risk-free rate $\mathrm{Rf}$, the yield on 10 -year US government bonds, which is $1.86 \%$, is accepted [9]. The data on the $\beta$ coefficient (taking into account financial leverage $\mathrm{D} / \mathrm{E}$ ) for companies, as well as the market premium for the risk of investing in shares ( $\mathrm{Rm}-\mathrm{Rf}$ ) were taken from the website [10]. In this case, the formula ( $\mathrm{Rm}-\mathrm{Rf})$ is calculated as the average value for a long period of time (1928 - early 2020). In addition, for comparability of market conditions, formula (1) was added with an additional S premium for country risk, which for Russia is $2.17 \%$ [10]. Thus, the formula (1) in the calculations is as follows:

$$
i=R_{f}+\beta\left(R_{m}-R_{f}\right)+S,
$$

where $\mathrm{S}$ is the country risk, $\%$.

Table 1. Calculation of discount rates for Russian companies of the mineral resources sector according to the stock market and the US government bond market.

\begin{tabular}{|c|c|c|c|c|c|c|c|c|}
\hline Company & $R_{f}, \%$ & $\beta$, un. & $\begin{array}{l}\left(\boldsymbol{R} m-\boldsymbol{R}_{f}\right) \\
\%\end{array}$ & $S, \%$ & $\begin{array}{l}i_{\text {usd }} \\
\%\end{array}$ & \begin{tabular}{|l}
$I N F_{\text {usd }}$, \\
$\%$ [12]
\end{tabular} & $\begin{array}{l}I N F_{r u b}, \\
\% \text { [11] }\end{array}$ & $i_{r u b}, \%$ \\
\hline SC Alrosa PJSC & 1.86 & 1.44 & 6.26 & 2.17 & 13.06 & 2.1 & 4.0 & 15.16 \\
\hline Gazprom PJSC & 1.86 & 1.31 & 6.26 & 2.17 & 12.21 & 2.1 & 4.0 & 14.30 \\
\hline Lukoil PJSC & 1.86 & 1.19 & 6.26 & 2.17 & 11.50 & 2.1 & 4.0 & 13.58 \\
\hline NOVATEK PJSC & 1.86 & 1.15 & 6.26 & 2.17 & 11.22 & 2.1 & 4.0 & 13.29 \\
\hline $\begin{array}{l}\text { MMC Norilsk } \\
\text { Nikel PJSC }\end{array}$ & 1.86 & 2.52 & 6.26 & 2.17 & 19.79 & 2.1 & 4.0 & 22.01 \\
\hline Rosneft PJSC & 1.86 & 1.86 & 6.26 & 2.17 & 15.66 & 2.1 & 4.0 & 17.81 \\
\hline $\begin{array}{l}\text { Surgutneftegaz } \\
\text { PJSC }\end{array}$ & 1.86 & 1.097 & 6.26 & 2.17 & 10.90 & 2.1 & 4.0 & 12.96 \\
\hline Tatneft PJSC & 1.86 & 1.14 & 6.26 & 2.17 & 11.15 & 2.1 & 4.0 & 13.21 \\
\hline \multicolumn{8}{|c|}{ Average value } & 15.29 \\
\hline \multicolumn{8}{|c|}{ Median value } & 13.94 \\
\hline
\end{tabular}

It should be noted that discount rates calculated according to formula (2) and presented in table 1 are dollar indicators iusd. During conversion of these indicators into the ruble equivalent, the translation formula based on the Fischer equation, widely used in assessment practice, was used:

$$
i_{r u b}=\frac{\left(1+i_{u s d}\right) \times\left(1+I N F_{r u b}\right)}{\left(1+I N F_{u s d}\right)}-1
$$

where $i_{\text {rub }}$ - discount rate in rubles, doll. units;

$i_{\text {usd }}$ - discount rate in dollars, doll. units;

$I N F_{\text {rub }}$ - forecast ruble inflation, doll. units;

$I N F_{\text {usd }}$ - forecast dollar inflation, doll. units;

As it can be seen from the calculations, the ruble discount rates range from $12.96 \%$ (Surgutneftegas PJSC) to $22.01 \%$ (MMC Norilsk Nickel PJSC). At the same time, the average value for the group of companies is $15.29 \%$, the median value is $13.94 \%$.

It should be noted that in contrast to the "mature" US securities market, which has more than a 100-year history of organized trading, the modern Russian market, existing for less 
than 30 years, has a relatively short retrospective. According to the authors of the article, the most significant are the historical data of the Russian stock market since 2005, during which there was a significant increase (about 90\%) in its capitalization. Thus, in this study, when calculating discount rates for mineral companies, statistical market data from 2005 to the beginning of 2020 were used.

The Russian securities market belongs to the "young" developing markets, for which, in comparison with the "mature" markets, uneven changes in prices, interest rates, indices, etc. are typical. For example, Fig. 1 shows the dynamics of the yield of 10-year federal loan bonds of Russia [12]. The chart below shows significant fluctuations in the interest rate of Russian government securities. Between 2005 and the present, the range of fluctuations is approximately from 6 to $14 \%$. The maximum value of the indicated rate of $16.54 \%$ at a short time was observed in December 2014 [12].

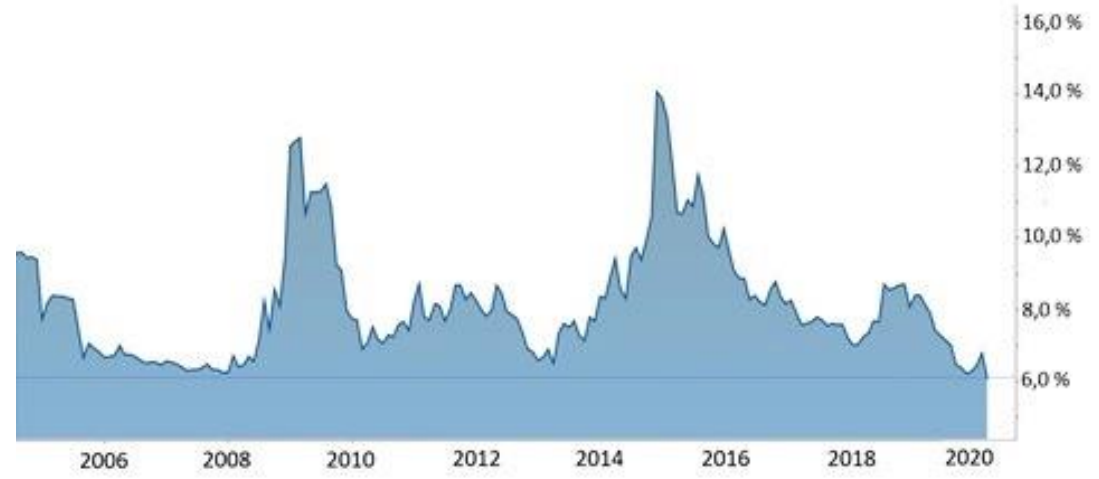

Fig.1. Yield dynamics of 10-year federal loan bonds of Russia (FLB).

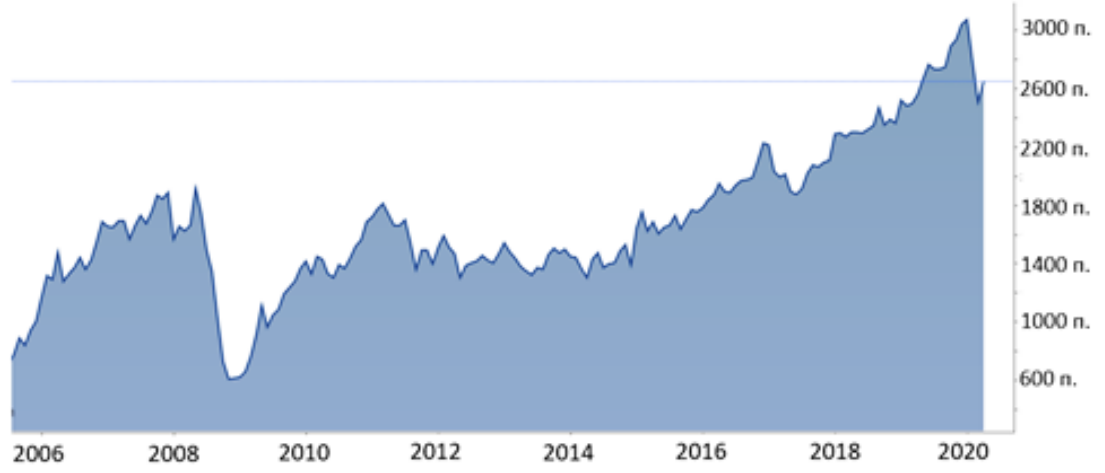

Fig.2. Dynamics of the Moscow Exchange stock sector (MOEX).

Fig. 2 presents the change in the Moscow Exchange (MOEX) stock index from 2005 to the present [12]. As it can be seen, the largest "jump", in this case, the fall of the index, falls at the end of 2008 - the beginning of 2009, its minimum value was 493 points. Further, during 2009 - early 2011 there was a significant increase in the indicator under consideration to more than 1800 points. This indicates an increase in the return on investment (excluding dividends) in the most liquid shares of Russian companies over this period by more than 3.6 times. After a long correctional wave of 2011 - 2013 follows an increase in the index to 3045 points at the beginning of 2020 .

Thus, all the above examples show the instability of the Russian economy, high volatility in the Russian securities market in general and in the stock market in particular. In its turn, 
significant fluctuations in the Moscow Exchange (MOEX) stock index indicate a "jump" in changes in the return on investment in shares of the largest issuing companies, reflect a large share of speculative operations in the total trading volume.

The results of calculation of the ruble discount rates for the largest companies in the mineral resources sector of Russia, which are based on data from the stock market and the government bond market of Russia (FLB) as of the beginning of 2020, are shown in table 2 . As a risk-free rate Rf, the yield on 10-year government bonds of Russia (FLB), which is 6.23 $\%$, is accepted [12]. The values of the $\beta$ coefficient are taken according to the information posted on the portal [12] for the respective companies. The market risk premium for investment in stocks ( $\mathrm{Rm}-\mathrm{Rf}$ ) is calculated as the average value for the period from 2005 to the beginning of 2020. Moreover, the evaluation of the market rate of return $\mathrm{Rm}$ for each year in the specified range of years was carried out according to the formula:

$$
R_{m}=\frac{P_{0}-P_{n}}{n P_{n}}+R_{d i v}
$$

where $R_{m}$ - average market yield, \%;

$P_{\mathrm{o}}$ - current value of the Moscow Exchange (MOEX) Stock Index, points;

$P_{n}$ - value of the Moscow Exchange (MOEX) Stock Index n periods ago, points;

$n$ - number of periods of the interval in which the average market yield is determined;

$R_{d i v}$ - average market dividend yield, defined as the ratio of dividends paid per year to the share purchase price, $\%$; according to [13] it is $7.27 \%$.

Table 2. Calculation of discount rates for Russian companies of the mineral resources sector according to the stock market and the government bond market of Russia

\begin{tabular}{|c|c|c|c|c|}
\hline Company & $\boldsymbol{R}_{\boldsymbol{f}}, \boldsymbol{\%}$ & $\boldsymbol{\beta}, \mathbf{u n}$. & $\boldsymbol{R}_{\boldsymbol{m}}-\boldsymbol{R}_{\boldsymbol{f}}, \boldsymbol{\%}$ & $\boldsymbol{i}_{\text {rub }}, \boldsymbol{\%}$ \\
\hline SC Alrosa PJSC & 6.23 & 0.75 & 17.59 & 19.42 \\
\hline Gazprom PJSC & 6.23 & 1.25 & 17.59 & 28.22 \\
\hline Lukoil PJSC & 6.23 & 1.08 & 17.59 & 25.23 \\
\hline NOVATEK PJSC & 6.23 & 0.75 & 17.59 & 19.42 \\
\hline $\begin{array}{c}\text { MMC Norilsk Nikel } \\
\text { PJSC }\end{array}$ & 6.23 & 1.31 & 17.59 & 29.28 \\
\hline Rosneft PJSC & 6.23 & 1.12 & 17.59 & 25.93 \\
\hline Surgutneftegaz PJSC & 6.23 & 1.05 & 17.59 & 24.70 \\
\hline Tatneft PJSC & 6.23 & 1.13 & 17.59 & 26.11 \\
\hline \multicolumn{5}{|c|}{ Average value } \\
\hline \multicolumn{4}{|c|}{ Median value } & 24.79 \\
\hline
\end{tabular}

The calculation of the discount rates themselves was carried out according to formula (1). Country risk was not taken into account, since the risk-free rate represents the yield in rubles equivalent and indirectly already contains macroeconomic risk for Russia. Table 2 shows that the range of the ruble discount rates obtained is from 19.42\% (SC Alrosa PJSC, NOVATEK PJSC) to $29.8 \%$ (MMC Norilsk Nickel PJSC), the average value is $24.79 \%$, median value $25.58 \%$. 


\section{Conclusions}

1. Comparing the results of calculations of the discount rates based on different information bases, namely, on the data of the US securities market (table 1) and the securities market of Russia (table 2), the following results can be summarized:

- for each selected large company of the mineral resources sector of Russia various ruble discount rates were received; moreover, calculations based on statistical data from the Russian securities market showed higher rates, and this, according to the authors, can negatively affect the assessment of potential investment projects in terms of their effectiveness;

- the largest discrepancy between the studied indicators for Gazprom PJSC (28.22 - 14.30 $=13.92 \%$ ), the smallest for SC Alrosa PJSC (19.42 - 15.16=4.26\%);

- the difference between the maximum and minimum discount rates when using data from the stock market and the US government bond market (from table 1: $22.01 \%-12.96 \%=$ $9.05 \%$ ) and Russia (from table 2: $29.8 \%-19.42 \%=10.38 \%$ ) is about $10 \%$;

- the average and median values of the calculated discount rates for the group of companies under consideration are significantly lower when using US securities market data (15.29 and $13.94 \%$, respectively) against Russian securities market data (24.79 and 25.58, respectively \%).

2. According to the authors of the article, the study showed that the use of a statistical database of US securities market when calculating discount rates is more appropriate, since they give the most objective results and are more acceptable when forecasting the return on investments. This is largely due to the duration of the retrospective period when calculating the premium for the risk of investing in stocks (from 1928 to the present), which smooths out the market volatility at certain crisis times. The Russian securities market has a short retrospective, during which there are uneven changes in indicators from 2005 to early 2020. So the use of Russian statistical information as a calculation base for discount rates and the possibility of their use in forecasting seem problematic.

3. The prospect of further research for the authors of the article is seen in the construction of special stochastic models for predicting discount rates used to evaluate investments in companies of the mineral resources sectorof Russia, which in particular takes into account the principles of the concept of general economic value described in work [14].

\section{References}

1. V. N. Podkorytov, L. A. Mochalova, USMU News, 2(54), 121 (2019)

2. S. G. Galevskiy, Economic Sciences, 12(1), 201 (2019)

3. P.E. Zhukov, Finance: theory and practice, 23(3), 35 (2019)

4. M. Giampietro, M. Guidolin, M. Pedio, European Journal of Operational Research, 265(2), 685 (2018)

5. L. Piccotti, Journal of Banking and Finance, 77, 230 (2017)

6. H. Wang, Research Letters, 21, 178 (2017)

7. A. Yu. Kuchko, O. A. Naumova, Bulletin of the Voronezh State University, 4, 171 (2019)

8. A.V. Kovalenko, V.D. Nikiforova, A.A. Nikiforov, Scientific journal of the NRU ITMO. Series "Economics and Ecological Management", 2, 26 (2019)

9. Portal «Economagic: Economic Time Series Page», URL: www.economagic.com

10. Portal «Damodaran Online», URL: http://pages.stern.nyu.edu/ adamodar/

11. Portal "Ministry of Economic Development of the Russian Federation.", URL: https://www.economy.gov.ru/

12. Portal "Investment", URL: www.investing.com 
13. Portal "Moscow Exchange", URL: www.moex.com

14. A.V. Dushin, V.V. Yurak, Eurasian Mining, 1, 11 (2018) 